\title{
4 \\ Wasted Days and Wasted Nights: Rose
}

In 1956, when I was four, my mother put me into this penguins' orphanage. That's the nuns. We called them 'the penguins'. Mum couldn't look after us. When my dad come home from war, things didn't go right for them. Dad was shot and also caught malaria in New Guinea and that affected him after the war. It done something to his thinking. He wasn't my dad. He went his way and mum went her way. Going back in them days, there was no money. We were poor. My mother couldn't afford to keep us. She couldn't look after us and so that's where we ended up-in Tufnell Home. The abuse I got from them bloody penguins if we didn't do our chores properly-like have the floor shining so you could see your face in it: we got the cane.

And there were smaller children there- too small to do any scrubbingbut the nuns would belt them. I stood in front of the little ones to cop it so they wouldn't get the cane for not doing their chores. Even though I was little myself, only four, I was bigger than the smaller ones-they were only two or three years old-and so I protected them. Once the nuns threw me in this bloody dark broom closet. It was pitch black. So I pushed one of the nuns and her glasses fell off. I laughed. She shut me in and said, 'Nothing will come of your life! You're the devil's daughter!'

They also used to make us wear these shoes that were too small and tight on our feet. I used to kick them off and walk with bare feet. I got caned for that and back in the broom closet I go. I was petrified because there was no light, no nothing. Even now I have to always have a light on and I have claustrophobia. They done that to me. Once, when I was nearly five, I was 
on the top of the slippery dip and one of the bigger kids pushed me off and I broke my arm. They took me to Brisbane Hospital and fixed my arm up in plaster. It was a bloody good weapon, that!

I didn't find out until then that Margaret was my sister. She was also in Tufnell. These two little kids, said, 'Hey Rosie! You know you got a sister in here?' I said, 'Huh? Where is she?' Margaret was standing right near the door. They said, 'That's your sister there-Margaret.' She was a year younger than me.

Then I got fostered out, with Margaret, to these morons who lived out in the country, out in Woop Woop. Being small we didn't know what was going on. We weren't told anything. My foster mother was an old crow. She was very strict. We had to empty out their piss pot and it had poop in it. This was our job every morning and also wipe everything down and pick up rubbish. There was no love. Nothing. Our foster mother made these ruddy old-fashioned hag dresses that I refused to wear. There was no way. They were old granny things, going back half a century before. I got mine and Margaret's dress and I ripped them up. I said, 'I'm not wearing it!'

We were sent to Benarkin School and, because I didn't understand the schoolwork, the bloody headmaster would give me the cane. I was nine years old. This went on day after day after day, in front of all the other children in class.

At home, the foster dad would take off his belt and whack us. One day, I went and got a razor and yelled to them, 'You dogs! You make us do this and do that! Watch out!'

I wasn't really going to cut myself. It was just a threat. I wasn't going to let them hurt Margaret. But I got sent back to Tufnell Home. I was 12. I didn't see Margaret again until 45 years later.

I kept running way from Tufnell Home. I'd run down to this old woman's place and hide under her house. She'd feed me and then she'd ring the nuns up to tell them where I was. The nuns called the cops. I hate cops. I was so terrified of them. I remember them grabbing my arm-one on each side. They took me back to Tufnell. But I kept running away. 
At 13, I got picked up again by the police and they took me back to Tufnell again but the nuns didn't want me this time and so they arranged it with welfare to have me taken to Goodna mental hospital. Welfare people from the government came and got me. I hate the government. They had no right putting me in there. There was nothing wrong with my mind.

It was 1965 when the head of staff at Goodna put me up in Ward 8 with violent mental patients. They bashed me up. The staff would take me into this room and give me shock treatment. I was put in a straightjacket and also given all these medications. For breakfast, lunch and tea, they had us on these drugs. There was one-Paraldehyde. When I had it, I didn't know what bloody day it was or where I was. Everything was strange and frightening. It took a couple of days before I come back to be myself. There was this bloody doctor who would examine me all over. The nurses were nasty to me and the other girls. They also took me down this bloody hallway, into a room, on a bed and strapped my legs, strapped my arms and put something like a halo on each side of my temples and then they plugged it in. When I had this shock treatment, I could be out for days. My eyes would all roll all the bloody way back. I wouldn't know what day it was. Everything was just all gone. It fries your brain. My hair looked like barbed wire and there was no toothbrush to clean my teeth. I just wanted to get out of Goodna. I was petrified of violent patients and I thought I would die from the shock treatment and all the drugs.

Something went wrong with one of the shock treatments. I ended up in the Brisbane Hospital. Then I was returned to Goodna in a freer ward with other teenage girls. At least I didn't get bashed up but I was still given medication and shock treatment about once a week or once a fortnight. I told one of the nurses how much it all hurt. She said, 'You girls shouldn't even be in here.' She was nice. She stuck up for us kids but she had to be very careful. Some of the girls had their families come and see them. The gate was wide open in that ward and that was my chance to piss off. The cops picked me up for vagrancy. They asked my name. They said, 'Oh! We've been looking for you!'

They caught me and put me back in Goodna and I was there until I was 14. I ran away again and the bastards didn't get me this time. I never, ever went back. I hitchhiked to the town of Roma. There, I met a bunch of street kids and stayed with them for a few months, under the bridge and also in rubbish bins to keep warm. There was about a dozen of us aged from 10 to 18 . Then it was time for me to move on. I wanted to be free 
as the breeze. I went with the wind. I hitchhiked to South Australia. I got picked up by truckies. I was petrified but I didn't know what I was going to do. They'd asked me where I'd like to be dropped off. I'd say, 'Just down here. I've got friends here.' I lied. I didn't have anyone. I'd keep heading off hoping to find a place where I'd be loved and looked after. I'd survive by taking food from garbage bins.

I ended up in a country town in South Australia by the beach. I met a new friend on the beach-Brenda. She was 14. I saw her mother once, sitting at the bus stop. She was Aboriginal. There were these little shacks at the beach. We'd hide in there and if we heard anyone, then we were off. Brenda and I stuck together. I could trust her with my life. I wasn't scared around her. We ended up in Sydney in Kings Cross. A truckie was going that way and he dropped us off there. He said someone there would come and help. We didn't know anything about Kings Cross just that there were more garbage bins for food and somewhere to hide.

We were standing on a corner at Kings Cross near the brothel bit. This woman came out to have a smoke and started asking us all these questions. She taught us how to get into prostitution. We used to call her 'Mother'. She was a nice person who looked after us but if you 'flipped the page over in the book', she was entirely different. She was nice but she was also mean. She taught us what do by showing us pictures. I didn't keep on doing what she wanted me to do. I did it for a while but something inside was telling me that it was the wrong thing. So she kicked me out and I had nowhere to stay. Brenda stayed on but I took off.

I had no money. I went wherever I could, wherever I felt safe-behind shops, in little humpies, garbage bins. I had a daughter-a rape baby. I don't know who her father is. I just don't know. Father unknown. I got raped on the streets. My stomach just kept on swelling. I had the baby in New South Wales. Karen was born with brain damage. Later, in the early 1980s, I took Karen to the specialist. I was telling him about some of my past. I asked him, 'Why was my daughter born like that? Was it all the medications that them bastards in Goodna was shoving into me?' He said, 'There is a good, possible chance because your daughter is not the only one. I've had so many children come to me who are crippled and other things.' I said, 'But getting back to me, you've read the medications they gave me-Paraldehyde and the other things.' He said, 'It's a good, possible, bloody chance.' 
Anyway, after Karen was born, we lived on the streets and I looked after her by going to different churches to get food and clothing. It was hard but we always slept where there were streetlights shining. I could at least see if there was someone sneaking around. Then I met a nice man, Carl, in the pub. He was 18. Karen was five. I went out with Carl for eight years. We came to Western Australia because Carl had friends over there. He had a job-a jack of all trades and helped look after Karen. I was a stay-at-home mum and bottle washer. Carl and I had two daughters of our own-Pipi and then Shannon. Pipi is a New Zealand name because Carl is a Kiwi. In 1978, when I was 27, he pissed off home to New Zealand. He wanted to marry his first cousin. It was very confusing for me. He's still with her to this day.

Then Carl didn't give me any money to look after the children. A woman took me to social security and I got money. They got me into one of their safe houses right out in the sticks. I didn't like it and they got us a place in Fremantle. Then I moved into a caravan park. That's where Pipi died in 1991 when she was 13. She suffered with bronchial asthma and she was on several tablets and the poison from those had built up in her system and killed her. It was on her death certificate. I still miss her. I'll never get over it. It's like there's a big piece taken out of my life. I still have all of her things with me. I've lived still loving her. If I feel sad I think of her, have a little cry and say, 'Pipi, I wish you were here.'

I moved to a farmhouse because Carl's brother come over for a holiday. I always kept in contact with Carl's mum. She's a very nice person and she lives in New South Wales. I moved from the farmhouse close to the city to be near doctors in case one of my children got sick. I was a mother, father, aunty, uncle and all to my children. I'm also a carer to Carl's brother. My daughter Karen is 45 now and Shannon is aged 40. As well as brain damaged, Karen is also an epileptic and she's been on a disability pension since she was 16 years of age. She lives in a unit as part of a complex not far from where I live. I help her with cooking and her housework. I love her to death but she's bloody hopeless! Shannon is married with five children and has got her own business-washing, cleaning and polishing cars. My eldest granddaughter has got two babies now.

I found my sister Margaret through social security. They got in contact with her to see if she wanted to get to know me. We got talking on the phone. Margaret came over here by plane and I met her at the airport. People from TV were there too. We were on TV and in the paper because 
we hadn't seen each other for 45 years. Margaret's not a rich person and it took time for her to save money to come to Perth. I was on top of the world when I saw Margaret. I couldn't believe it. I wanted to get on top of the highest roof and sing it out. I was just so happy. Margaret stayed with us. We shared the one bed! Margaret stayed for about a week and a half and then she had to get back to her husband and her family. I didn't want Margaret to go back. We haven't seen one another since. We talk on the phone.

Them welfare mongrels took my whole life from me. When I was a little girl, I always wanted to be in the army. Always. Even when I grew up and was doing other things, I still wanted to be in the army. But I wasn't fit to be in the army. I've had no education. That was a dream of mine-be in the army, own my own home, money in the bank. Nup. It didn't happen because bloody Goodna and the bloody welfare mob and the politician dorks took my life, took my dream.

I've got no recall of years of my life. I just can't remember. And when I speak up about my childhood I talk the way I did when I was a child. Also I don't want to go down that path of things that happened after I came out of Goodna and long before I met Carl. I don't talk about that because I still suffer from deep depression. But there's also bits and pieces missing that I don't know anything about. That has to be from the shock treatment because I wasn't into drugs or anything like so what else could it have been? There was nothing wrong with my brain before they gave me all the shock treatments and drugs. Wasn't then but now there's a lot of things I just can't remember. Margaret did all the talking for me with the commission because it's too depressing for me. I've never applied for redress. I don't understand it.

Carl's brother is 50 . He's disabled with hip problems and he's an alcoholic. I get paid for caring for him. They call it 'live-in carer'. We live in a twobedroom duplex in a housing estate. We rent it off Homes West that helps people with disabilities. He's got his room and I've got mine. When he's pissing me off I go and tell him, 'Go and piss off to the back yard.'

Margaret and I have uncles and half-sisters who don't want nothing to bloody do with us. They're married into rich families. Margaret and I aren't good enough to be related to them. Theyve got everything. Margaret and I have bloody nothing. It gets to me these days. Family is supposed to stick together. That's what I always believe. I find it very hard to trust 
anybody. I don't mix with other people. I keep to myself. There's things I like doing like dancing but I don't go out anywhere. I'm at home here and I do my own thing. That's my whole bloody life-just gone right to the shit. At times it's hard but I've managed and I've done everything all my life. I haven't asked anyone for anything. I just do what I've got to do. I go to my room to talk to my daughters on the phone and I play country music. My favourite song is 'Wasted Days and Wasted Nights' by Freddy Fender.

Even though I live in the poor house, I'm a good person and I'd do anything for anyone. That's all I can do. I reckon between the bloody welfare mob and the bloody government, they oughta buy me a bloody house so I can have my daughter Karen live with me. It would be heavenly. I reckon they owe that to me. 
This text is taken from Goodna Girls: A History of Children in a Queensland Mental Asylum, by Adele Chynoweth, published 2020 by ANU Press, The Australian National University, Canberra, Australia.

doi.org/10.22459/GG.2020.04 